\title{
Linear Atrophoderma of Moulin on face: An unusual location
}

\section{Yüzde yerleșen lineer Moulin atrofoderması: Atipik lokalizasyon}

\section{Ezgi Özkur, ๑ Illknur Kıvanç Altunay, ๑ Uğur Çelik*, ๑ Damla Demir**, ๑ Deniz Tuncel***}

University of Health Sciences Turkey, Șișli Hamidiye Etfal Training and Research Hospital, Clinic of Dermatology, Istanbul, Turkey

*Medipol University Faculty of Medicine, Department of Dermatology, İstanbul, Turkey

**University of Health Sciences Turkey, Ümraniye Training and Research Hospital, Clinic of Dermatology, İstanbul, Turkey

***University of Health Sciences Turkey, Șișli Hamidiye Etfal Training and Research Hospital, Clinic of Pathology, Istanbul, Turkey

Keywords: Atrophoderma, blaschko's lines, face

Anahtar Kelimeler: Atrofoderma, blaşko çizgileri, yüz

\section{To The Editor,}

Linear Atrophoderma of Moulin (LAM) is characterized by acquired unilateral hyperpigmented depressed band like skin lesions following blaschko's lines. Moulin et al. ${ }^{1}$ first defined the condition in 1992 and, later, Baumann et al. ${ }^{2}$ reported similar features on a patient and named the condition as LAM.

In our 2 case reports, we described first a 26-year-old female with asymptomatic hyperpigmented lesions since one year. On physical examination, there was a depressed band-like lesion on the right side of chin along the neck following blaschko's lines (Figure 1A).

Our second case was a 23-year old female patient with band like lesions over her right side of nasolabial region and chin since 3 years. The topography was unilateral and following blaschko's lines. Physical examination showed linear atrophic slightly hyperpigmented skin lesion without sclerosis (Figure 1B). Both patients had no history of preceding trauma, cosmetic procedure, signs of inflammation or family history of similar illness. There was no other apparent clinical symtoms such as pain or pruritus or systemic symptoms. Histological examinations of both patients showed mild perivascular inflammatory infiltrate of lymphocytes and few melanophages in the papiller dermis which was non spesific (Figure 2A, B). Laboratory investigations of patients

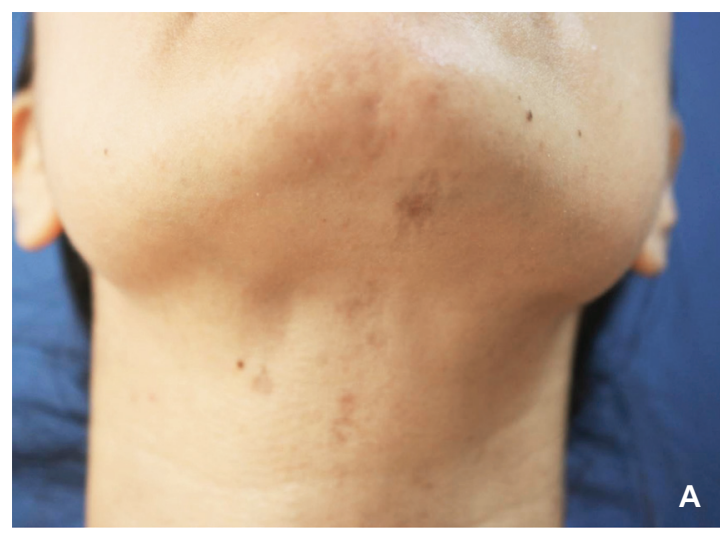

Figure 1A. Depressed band like hyperpigmented lesions over left side of chin along the neck

Address for Correspondence/Yazıșma Adresi: Ezgi Ozkur MD, Sișli Hamidiye Etfal Training and Research Hospital, Department of Dermatology, istanbul, Turkey Phone: +90 5303886781 E-mail: ezgierdal@hotmail.com Received/Geliş Tarihi: 02.10.2019 Accepted/Kabul Tarihi:18.11.2019 ORCID: orcid.org/0000-0002-9136-7021

CCopyright 2020 by Turkish Society of Dermatology and Venereology

Turkderm - Turkish Archives of Dermatology and Venereology published by Galenos Yayınevi. 


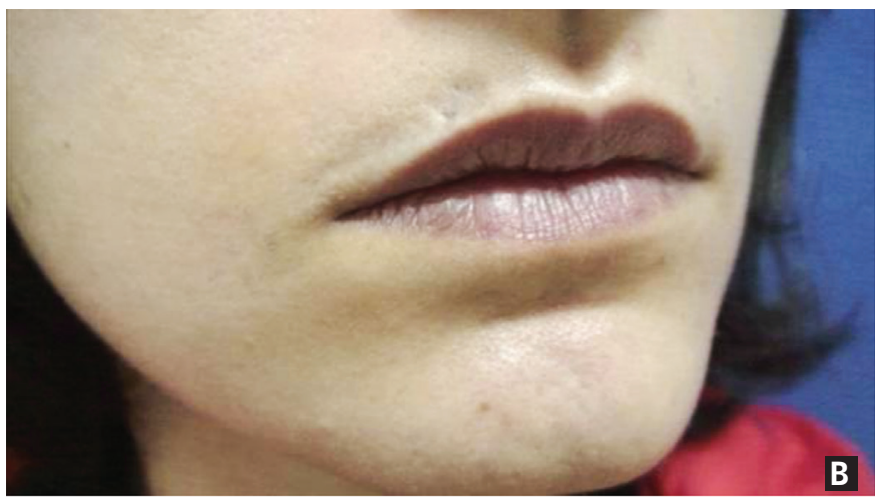

Figure 1B. Depressed band like slightly hyperpigmented lesions over right side of nasolabial region and chin

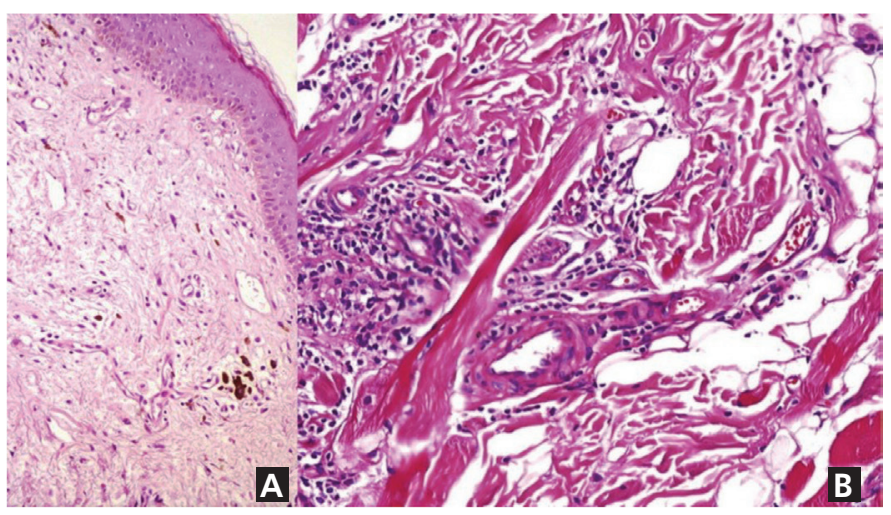

Figure 2A. Perivascular inflammatory infiltrate of lymphocytes and few melanophages in the papiller dermis were seen on first patients', x20 hematoxylin and eosin (H\&E) stain

Figure 2B. Perivascular inflammatory infiltrate in second patient, x40 H\&E stain

including full blood count, erythrocyte sedimentation rate, renal profile, liver function test, antinuclear antibodies were all negative or within the normal range. The diagnosis of LAM was made. Patients were prescribed with betamethasone, $0.1 \%$ cream twice daily.

Clinical presentations of LAM were mostly consistent with hyperpigmentation and atrophoderma following blaschko's lines on the trunk or limbs. Only 3 patients were reported with face presentation in literature so far ${ }^{3}$. Histopathological features described as non-spesific in literature. In a review with 28 cases the commonest histolpathological finding is reported as mild perivascular inflammatory infiltrate of lymphocytes.

The differential diagnosis include idiopathic atrophoderma of pasini and pierini, lichen striatus or linear morphea. Atrophoderma of pasini and pierini is characterized by hyperpigmented and atrophic skin lesions and exhibits a spectrum of alterations in elastic fibers in histopathological examination which however never follows blaschko's lines. Lichen striatus is also common acquired self-limited linear eruption in childhood that follows blaschko's lines but histopathology of lichen striatus shows a polymorphic epidermal reaction process of variable lichenoid and spongiotic changes. Morphea can also follow blaschko's lines but absence of preceeding inflammation, dermal induration, scleroderma or sclerosis on histopathology, led us to a diagnosis of $\mathrm{LAM}^{4}$. There is no effective treatment for LAM and main concern is esthetic. Topical corticosteroids, heparin, penicillin, potassium benzoat, topical calcipotriol have been proposed but there isn't any satisfactory treatment results with these treatments reported so far. In another case report, authors reported of improvement pigmentation and atrophy with methotrexate ${ }^{5}$. We present these cases to raise awareness of this condition, because we think LAM is an underrecognized entity and needs further studies.

\section{Ethics}

Informed Consent: Informed consent was obtained from the patient. Peer-review: Externally peer-reviewed.

\section{Authorship Contributions}

Surgical and Medical Practices: E.Y.E., G.V., Concept: Ç.T., H.M.E., Design: Ç.T., H.M.E.,Data Collection or Processing: Ç.T., Analysis or Interpretation: Ç.T., H.M.E., Literature Search: Ç.T., E.Y.E., G.V., Writing: Ç.T.

Conflict of Interest: No conflict of interest was declared by the authors.

Financial Disclosure: The authors declared that this study has received no financial support.

\section{References}

1. Moulin G, Hill MP, Guillaud V, Barrut D, Chevallier J, Thomas L: [Acquired atrophic pigmented band-like lesions following Blaschko's lines]. Ann Dermatol Venereol 1992;119:729-36.

2. Baumann L, Happle R, Plewig G, Schirren CG: [Atrophodermia linearis Moulin. A new disease picture, following the Blaschko lines]. Hautarzt 1994;45:231-6

3. Darung I, Rudra O, Samanta A, Agarwal M, Ghosh A: Linear Atrophoderma of Moulin over Face: An Exceedingly Rare Entity. Indian J Dermatol 2017:62:214-5

4. Tan SK, Tay YK: Linear atrophoderma of Moulin. JAAD Case Rep 2016;2:10-

5. Zaouak A, Ghorbel HH, Benmously-Mlika R: A case of linear atrophoderma of Moulin successfully treated with methotrexate. Dermatol Ther 2014;27:153- 